\title{
The Nature Of Codes Of Business Ethics:
}

\section{A Strategic Perspective}

\author{
Fred R. David \\ Auburn University \\ Auburn, Alabama \\ Don Robin \\ Louisiana Tech University \\ Ruston, Louisiana. \\ Mike Giallourakis \\ Mississippi State University \\ Mississippi State, Mississippi
}

The role of business ethics in corporate strategy has been largely ignored in theory and practice. An unfortunate result of this phenomena is that many organizations today encounter ethics problems and pursue strategies that appear not to be based on a foundation of ethics. Business ethics should become an integral part of strategy formulation, implementation, and evaluation activities in all types and sizes of organizations.

Ethics is sometimes defined as the clarification of what constitutes human welfare and the conduct necessary to promote it [9]. Ethicians use the term "ethics" to refer to the study of what is morally right or wrong [21]. Business ethics is a specialized study of moral judgments and values that focuses on individual behavior in organizations $([3],[6],[17]])$. In his book Business and Society, Steiner [25] defines business ethics as behavior "that is fair and just, over and above obedience to ... laws ... and regulations. Loucks [23], chief executive officer of Baxter Travenol, says ethics isn't a matter of law or public relations or religon; rather, it is a matter of trust. Discussing business ethics with any degree of honesty means balancing the interests of an organization's stakeholder [23]. For example, employees want high wages and good benefits, whereas customers want low prices and high quality. Thus, division $\mathrm{XYZ}$ may be divested while division $\mathrm{ABC}$ is strengthened. The risk of an airplane engine failing by a tenth of one percent may be approved in order to reduce manufacturing costs and price by thirty percent? Difficult decisions such as these characterize business ethics.

Newspapers and business magazines daily report legal and moral breaches of ethical conduct in organizations. Bank fraud losses for the decade of the 1980s are expected to exceed $\$ 20$ billion, compared to losses of less than $\$ 1.5$ billion for the decade of the 1970s. Baxter Travenol Laboratories, IBM, Caterpillar Tractor, and Celanese are example firms that have formalized their own code of business ethics. The chief executive officer of these and many other firms have spelled out the ethical standards

Journal of Business Strategies, Volume 6, Number 1 (Spring 1989) 
and values expected of all their managers and employees. Corporate strategy reflects an understanding of the values of organizational members and constituencies of the firm. When stakeholders of the firm benefit from certain strategies, while other stakeholders lose. Ethical tradeoffs characterize strategic choice.

The purpose of this article is to report the findings of a recent study that examined the codes of business ethics of major companies in the United States. The research results could provide a basis for improving codes of business ethics. Using content analysis and a dustering procedure, specific variables currently being included in corporate codes of business ethics are identified and grouped into categories. Profiles of the codes of business ethics of manufacturing and service firms are developed. An approach for developing an effective code of business ethics is proposed.

The findings of this study could be useful to top managers, owners of small businesses, and other strategists who are responsible for developing a code of business ethics for their organization. The results could also benefit researchers who develop theory and test hypotheses regarding the relationship between business ethics and organizational behavior.

\section{Literature Review}

An integral part of the responsibility of all managers is to provide ethics leadership by constant example and demonstration [11]. However, primary responsibility for having an effective code of business ethics rests largely with a firm's top managers or strategists. Drucker ([12], p. 462-63) contends that no individual should ever become a strategist unless that person is willing to have his or her character serve as the model for subordinates:

A man (or woman) might know too little, perform poorly, lack judgment and ability, and yet not do too much damage as a manager. But if that person lacks in character and integrity - no matter how knowledgeable, how brilliant, how successful - he destroys. He destroys people, the most valuable resource of the enterprise. He destroys spirit. And he destroys performance. This is particularly true of individuals at the head of an enterprise. For the spirit of an organization is created from the top. If an organization is great in spirit, it is because the spirit of its top people are great. If it decays, it does so because the top rots; as the proverb has it, "Trees die from the top."

Previous research indicates that a clear code of business ethics can provide guidance and impetus for managerial leadership $([19],[20],[22])$. Barnard ([2], p. 278) concluded that a lack of moral responsibility on the part of a strategist will be detrimental to an organization. He says, "The best solution in such cases would often be resignation, demotion, or discharge." Effectively mixing moral and business imperatives and making appropriate decisions in complex situations is a prerequisite for having strategic responsibilities $([15],[22],[23],[27])$. One reason why top managers 
are paid so much more than middle managers is because they take the moral risks of the firm [1]. Owners of businesses, chief executive officers, and top administrators are responsible for developing, communicating, and enforcing a set of values for their organization $([2],[15])$.

Horton [18] emphasizes that personal financial gain is often an underlying motive for unethical conduct in organizations. Gellerman $([14]$, p. 88]) identifies three rationalizations that often explain why individuals sometimes act unethically in ways that ultimately inflict harm to their organization:

1. Since everyone else does it, the unethical action is not really illegal or immoral.

2. Since the corporation will benefit, the unethical action is justified.

3. Since no one will find out about the unethical action, it is worth doing.

The general value structure rooted in religion, coupled with local, state, and federal laws, can provide a baseline for appropriate ethical behavior in organizations [13]. Laczniak and Naor [21] stress that bases for ethical conduct vary across different foreign countries. They assert that strategists of multinational firms are generally less familiar with foreign markets than with domestic markets. This varying degree of familiarity, coupled with pervasive ethnocentric orientations, makes ethical misjudgments more likely for domestic companies operating in foreign countries.

There is a feeling by some practitioners and academicians today that codes of business lack much "impact" [7]. For example, Cressey and Moore ([10], p. 73) suggest that any improvements in business ethics taking place in the last decade are not from codes of business ethics themselves, but rather have stemmed from conditions imposed by outsiders. These researchers $([10]$, p. 73$)$ conclude that codes of business ethics tend to imitate the criminal law and thus contain few innovative ideas about how ethical standards of a firm can be improved. Another study by Chonko and Hunt ([8], p. 356) involving marketing managers found that the existence of corporate codes of business ethics seems to be unrelated to the extent of ethical problems in marketing management. Previous research thus accents the need for an improved understanding of codes of business ethics, so that more effective codes can be developed.

\section{Method and Analysis}

\section{Sample}

A personal letter was mailed to the chief executive officer of all firms included in the Business Week 1,000 list of manufacturing and service firms. The letter asked for a copy of the firm's code of business ethics. Business Week uses market value, determined by multiplying a firm's stock market price by its number of shares outstanding, to annually determine the top 1,000 corporations in America. Market value is a composite measure of how large and healthy a firm is at a given point in time.

A total of 178 responses were received, 83 firms providing a formal code of business ethics (46\%) and 95 chief executive officers indicating their firm had not developed a 
code of business ethics ( $54 \%$ ). Among the 83 firms providing a formal code of business ethics, there were 32 manufacturing firms and 51 service firms. This ratio of manufacturing firms to service corporations is representative of the entire Business Week 1,000 population of companies. Responding firms in this study do not differ significantly from nonrespondents on organizational size or performance measures. However, it may be that 46 percent overestimates the actual percentage of firms with codes of business ethics, since nonresponding firms are likely to be those without formal codes.

\section{Content Analysis}

Content anaylysis was used to evaluate the sample codes of business ethics. Content analysis entails selecting a message to be studied, developing categories for measurement, measuring frequency of appearance of the categories using coding rules, applying an appropriate test to the data collected, and then drawing conclusions $([4],[16])$. Content analysis is a qualitative research technique often used for analyzing message content and message handling [16]. In this study, two coders independently read the sample documents and recorded the presence of particular variables in the documents. Variables were recorded just as they appeared in the documents. A total of 28 variables were found in the sample codes of business ethics. An overall interrater reliability coefficient of 100 percent indicated that the two raters were able to easily identify the ethics variables in the sample documents.

The 28 ethics variables found in the sample codes are listed in Table 1 in order of frequency of occurrence. The most often included variable was "Conduct Business in Compliance with All Laws;" the least often included variable was "Firearms at Work are Prohibited."

\section{Cluster Analysis}

The 28 variables were grouped into clusters using a two-step process. First, the two coders independently grouped the variables under broader, more descriptive headings where appropriate. The broader headings generated by the two coders were then compared and titles for these groupings were agreed upon. Suggested labels for the three clusters were as follows:

Cluster 1: Be a Dependable Organizational Citizen

Cluster 2: Do Not Do Anything Unlawful or Improper that will Harm the Organization

Cluster 3: Be good to Our Customers

As shown in Table 2, the three "named" clusters accounted for 23 of the 28 variables. Five variables did not fit into a cluster.

The second step in the cluster analysis process involved a third reviewer. This person selected a random sample of ten codes and independently placed the ethics variables into categories identified as clusters by the two previous coders. The ten codes contained 218 ethics variables. This check for reliablility of the raters produced perfect agreement with previous efforts. The third reviewer correctly classified all 218 
items. Given the broad cluster labels and itemized character of the codes, this high test-retest rate of reliability should not be surprising.

Table 1

Variables Included in the Sample

Codes of Business Ethics ${ }^{a}$

1. Conduct Business in Compliance with All Laws
2. Payments for Unlawful Purposes are Prohibited
3. Avoid Outside Activities that Impair Duties
4. Comply with all Antitrust and Trade Regulations
5. Comply with Accounting Rules and Controls
6. Bribes are Prohibited
7. Maintain Confidentiality of Records
8. Participate in Community and Political Activities
9. Provide Products and Services of the Political Activities
10. Exhibit Standards of Personal Integrity and Conduct
11. Do Not Propogate False or Misleading Information
12. Perform Assigned Duties to the Best of Your Ability
13. Conserve Resources and Protect the Environment
14. Comply with Safety, Health, and Security Regulations
15. Racial, Ethnic, Religious, and Sexual Harassment at Work is
Prohibited
16. Report Unethical and Illegal Activities to Your Manager
17. Convey True Claims in Product Advertisements
18. Make Decisions Without Regard for Personal Gain
19. Do Not Use Company Property for Personal Benefit
20. Demonstrate Courtesy, Respect, Honesty, and Fairness
21. Mlegal Drugs and Alcohol at Work are Prohibited
22. Manage Personal Finances Well
23. Employees are Personally Accountable for Company Funds
24. Exhibit Good Attendance and Punctuality
25. Follow Directives of Supervisors
26. Do No Use Abusive Language
27. Dress in a Business-Like Attire
28. Firearms at Work are Prohibited
a The variables are presented in descending order with regard to
fequency of occurrence in the sample documents.

To further check the validity of the cluster groupings, each organization received a 0 or 1 for each of the 28 ethics variables to indicate whether that variable appeared in their code of ethics. The three coders jointly completed this analysis. A zero indicated that the particular variable was not included in the particular code, whereas a one indicated that the variable was included. A $28 \times 28$ correlation matrix between the variables was produced. Correlations among variables in the cluster groupings were then subjected to a test for internal consistency using coefficient alpha. The coefficient 
alpha values for the three named clusters were $0.84,0.76$, and 0.66 respectively. These relatively high values indicate significant homogeneity within clusters.

\section{Table 2}

Clusters of Variables Found in Corporate Codes of Business Ethics

Cluster 1: Be a Dependable Organizational Citizen

1. Comply with Safety, Health, and Security Regulations

2. Demonstrate Courtesy, Respect, Honesty, and Fairness

3. Ilegal Drugs and Alcohol at Work are Prohibited

4. Manage Personal Finances Well

5. Exhibit Good Attendance and Punctuality

6. Follow Directives of Supervisors

7. Do Not Use Abusive Language

8. Dress in a Business-Like Attire

9. Firearms at Work are Prohibited

Cluster 2: Do Not Do Anything Unlawful or Improper that Will Harm the Organization

1. Conduct Business in Compliance with All Laws

2. Payments for Unlawful Purposes are Prohibited

3. Bribes are Prohibited

4. Avoid Outside Activities that Impair Duties

5. Maintain Confidentiality of Records

6. Comply with all Antitrust and Trade Regulations

7. Comply with Accounting Rules and Controls

8. Do Not Use Company Property for Personal Benefit

9. Employees are Personally Accountable for Company Funds

10. Do Not Propogate False or Misleading Information

11. Make Decisions Without Regard for Personal Gain

Cluster 3: Be Good to Our Customers

1. Convey True Claims in Product Advertisements

2. Perform Assigned Duties to the Best of Your Ability

3. Provide Products and Services of the Highest Quality

Unclustered Variables

1. Exhibit Standards of Personal Integrity and Conduct

2. Racial, Ethnic, Religious, and Sexual Harassment at Work is Prohibited

3. Report Unethical and Dlegal Activities to Your Manager

4. Participate in Community and Political Activities

5. Conserve Resources and Protect the Environment 


\section{Comparing Manufacturing and Service Firms}

Service organizations, such and banks and utilities, were heavy users of variables in Cluster 1 titled "Be a Dependable Organizational Citizen." Example firms including many Cluster 1 variables were Bank of Boston, City National Bank, Wachovia Corporation, Wisconsin Electric Power, ITT, Northeast Utilities, and Texas Utilities. On the other hand, manufacturing firms, such as Exxon, Dow Chemical, Monsanto, Sara Lee, Dupont, and Celanese, more often included ethics variables in Cluster 2 titled "Do Not Do Anything Unlawful or Improper that will Harm the Organization," and Cluster 3 titled "Be Good to our Customers."

A detailed profile of the sample codes of business ethics of manufacturing firms and service firms was developed. As indicated by significant $t$-values in Table 3, manufacturing and service firms' codes of business ethics differ significantly on twelve variables. Specifically, the codes of manufacturing firms more often include the following six variables:

1. Conduct Business in Compliance with All Laws

2. Comply with all Antitrust and Trade Regulations

3. Provide Products and Services of the Highest Quality

4. Perform Assigned Duties to the Best of Your Ability

5. Conserve Resources and Protect the Environment

6. Comply with Safety, Health, and Security Regulations

Codes of business ethics of service firms more often include the following six variables:

1. Avoid Outside Activities that Impair Duties

2. Do Not Use Company Property for Personal Benefit

3. Ilegal Drugs and Alcohol at Work are Prohibited

4. Manage Personal Finances Well

5. Make Decisions Without Regard for Personal Gain

6. Dress in a Business-Like Attire

\section{Implications}

Variables included in Cluster 1 titled "Be a Dependable Organizational Citizen" all seem to direct the employee to be "nice." These variables focus upon desirable characteristics of people, such as to be courteous, honest, fair, and punctual; to not use drugs or alcohol, and to manage personal finances well. These kinds of personal characteristics are important for manufacturing as well as service employees, so perhaps manufacturing firms should more often include Cluster 1 variables in their code of business ethics. Being dishonest, tardy, or drug dependent can obviously disrupt 
manufacturing operations and reduce efficiency and productivity to an alarming extent. Although manufacturing employees typically do not interact with customers and the general public as much as employees of service firms, Cluster 1 type variables can still dramatically affect the competitiveness of manufacturing firms.

Table 3

Comparing Codes of Business Ethics of Manufacturing Firms with Service Firms $(n=83)$

\begin{tabular}{|c|c|c|c|c|}
\hline & $\begin{array}{l}\text { Variables Included } \\
\text { In The Sample Codes } \\
\text { Of Business Ethics }\end{array}$ & $\begin{array}{c}\text { Mean For } \\
\text { Manufacturing } \\
\text { Firms }(n=32)\end{array}$ & $\begin{array}{c}\text { Mean For } \\
\text { Service } \\
\text { Firms }(n=51)\end{array}$ & $t$-value \\
\hline 1 . & $\begin{array}{l}\text { Conduct Busiress In } \\
\text { Compliance With All laws }\end{array}$ & .7500 & .5098 & $2.21^{*}$ \\
\hline 2. & $\begin{array}{l}\text { Payments For Unlawful } \\
\text { Purposes Are Prohibited }\end{array}$ & .6363 & .5882 & $0.61^{*}$ \\
\hline 3. & $\begin{array}{l}\text { Avoid Outside Activities } \\
\text { That Impair Duties }\end{array}$ & .5938 & .8039 & $-2.11^{*}$ \\
\hline 4. & $\begin{array}{l}\text { Comply With All Antitrust } \\
\text { And Trade Regulations }\end{array}$ & .5983 & .3529 & $2.18^{*}$ \\
\hline 5. & $\begin{array}{l}\text { Comply With Accounting } \\
\text { Rules And Controls }\end{array}$ & .5625 & .5490 & 0.12 \\
\hline 6. & Bribes Are Prohibited & .5313 & .7059 & -1.62 \\
\hline 7. & $\begin{array}{l}\text { Maintain Confident- } \\
\text { tiality of Records }\end{array}$ & .5000 & .7059 & -1.91 \\
\hline 8. & $\begin{array}{l}\text { Participate In Community } \\
\text { And Political Activities }\end{array}$ & .4375 & .6275 & -1.70 \\
\hline 9. & $\begin{array}{l}\text { Provide Products And Services } \\
\text { Of The Highest Quality }\end{array}$ & .4375 & .1765 & $-2.66^{* *}$ \\
\hline 10. & $\begin{array}{l}\text { Exhibit Standards Of Personal } \\
\text { Integrity And Conduct }\end{array}$ & .4375 & .3137 & 1.14 \\
\hline 11. & $\begin{array}{l}\text { Do Not Propogate False Or } \\
\text { Misleading Information }\end{array}$ & .3438 & .3333 & 0.10 \\
\hline 12. & $\begin{array}{l}\text { Perform Assigned Duties } \\
\text { To The Best Of Your Ability }\end{array}$ & .3125 & .0980 & $2.30^{*}$ \\
\hline 13. & $\begin{array}{l}\text { Racial, Ethnic, Religious, } \\
\text { And Sexual Harassment At } \\
\text { Work Is Prohibited }\end{array}$ & .2188 & .2353 & -0.17 \\
\hline 14. & $\begin{array}{l}\text { Conserve Resources And } \\
\text { Protect The Environment }\end{array}$ & .2813 & .0588 & $2.55^{* *}$ \\
\hline 15. & $\begin{array}{l}\text { Comply With Safety, Health, } \\
\text { And Security Regulations }\end{array}$ & .2500 & .0588 & $2.26^{*}$ \\
\hline 16. & $\begin{array}{l}\text { Report Unethical And Illegal } \\
\text { Activities To Your Manager }\end{array}$ & .1563 & .2745 & -1.24 \\
\hline
\end{tabular}




\begin{tabular}{|c|c|c|c|c|}
\hline & $\begin{array}{l}\text { Variables Included } \\
\text { In The Sample Codes } \\
\text { Of Business Ethics }\end{array}$ & $\begin{array}{c}\text { Mean For } \\
\text { Manufacturing } \\
\text { Firms }(n=32) \\
\end{array}$ & $\begin{array}{l}\text { Mean For } \\
\text { Service } \\
\text { Firms }(n=51)\end{array}$ & $t$-value \\
\hline 17. & $\begin{array}{l}\text { Convey True Claims In } \\
\text { Product Advertisements }\end{array}$ & .1563 & .0980 & 0.79 \\
\hline 18. & $\begin{array}{l}\text { Make Decisions Without } \\
\text { Regard For Personal Gain }\end{array}$ & .0938 & .2745 & $-2.02^{*}$ \\
\hline 20. & $\begin{array}{l}\text { Do Not Use Company Property } \\
\text { For Personal Benefit }\end{array}$ & .0625 & .3725 & $-3.83^{* * *}$ \\
\hline 21. & $\begin{array}{l}\text { Demonstrate Courtesy, Respect, } \\
\text { Honesty, And Fairness }\end{array}$ & .0625 & .1765 & -1.65 \\
\hline 23. & $\begin{array}{l}\text { Manage Personal Finances } \\
\text { Well }\end{array}$ & .0000 & .1373 & $-2.23^{*}$ \\
\hline 24. & $\begin{array}{l}\text { Illegal Drugs And Alcohol } \\
\text { At Work Are Prohibited }\end{array}$ & .0000 & .1176 & $-2.04^{*}$ \\
\hline 25 . & Dress In Business-Like Attire & .0000 & .0784 & $-1.63^{*}$ \\
\hline 26. & $\begin{array}{l}\text { Firearms At Work Are } \\
\text { Prohibited }\end{array}$ & .0000 & .0588 & -1.40 \\
\hline 27. & Do Not Use Abusive Language & .0000 & .0588 & -1.40 \\
\hline 28. & $\begin{array}{l}\text { Exhibit Good Attendance } \\
\text { And Punctuality }\end{array}$ & .0000 & .0196 & -0.79 \\
\hline
\end{tabular}

${ }^{*} \mathrm{p}<.05 ;^{* *} \mathrm{p}<.01 ;{ }^{* * *} \mathrm{p}<.001$

Notes to accompany Table 3

1. The mean values could range from .0000 (No firms included this variable in their code of business ethics) to 1.0000 (All firms included this variable in their code of business ethies).

2. The variables are listed in order of frequency of occurrence among manufacturing firms. For example, 75 percent of all manufacturing firms included the "Conduct Business in Compliance With All Laws" variable.

3. Manufacturing firms have a Standard Industrial Classification (SIC) Code of less than 40; service firms have SIC Codes ranging from 40 to 99 , ie the first two digits.

Cluster 2 titled "Do Not Do Anything Unlawful or Improper that will Harm the Organization" contained the largest number of variables [11] and was by far the most subscribed to group. Over 50 companies included many of these variables in their code of business ethics. The legalistic character of the variables in Cluster 2 seem to give it a preventive tone designed to protect the organization, rather than a sense of values to guide behavior. For example, two of the variables in Cluster 2 deal with bribery. The issue seems to be that bribery is prohibited because it is against the law, and the organization could get into trouble if bribes were given or taken. This is certainly a desirable message, but it is substantially different from an organizational 
value statement such "Do Unto Others As You Would Have Them Do Unto You." Value statements are broad based and could be proactive in shaping behavio. A more appropriate forum for communicating rules of the firm may be in a policy manual, rather than a code of busines ethics. Managers of both manufacturing and service firms should perhaps consider including values to a greater extent in their code of business ethics. Values seek ethical behavior "beyond the law for the good of all."

Cluster 3 titled "Be Good To Our Customers" contained variables that concern ways in which the behavior of employees could satisfy customers, such as to "Convey True Claims in Product Advertisements." Organizations including these variables in their code exhibited no tendency toward a specific industry, but rather came from a variety of industries. Customers are what give meaning to a business, so perhaps both manufacturing and service organizations should include additional Cluster 3 type variables in a code of business ethics to reflect the primary importance of obtaining and keeping customers.

Among the unclustered variables, "Exhibit Standards of Personal Integrity and Conduct" was included in 31 of the sample codes of business ethics. Two unclustered variables appeared in 19 codes. These were "Racial, Ethnic, Religious, and Sexual Harassment at Work is Prohibited" and "Report Unethical and Illegal Activities to Your Manager." Included in 46 sample codes of business ethics, the variable "Participate in Community and Political Activities" was the most popular of the unclustered items, being included by 46 companies. Finally, only 12 of 83 sample codes of business ethics included the "Conserve Resources and Protect the Environment" variable.

\section{Developing a Code of Business Ethics}

An effective approach for developing a code of business ethics could be to identify key ethical threats and opportunities facing the company and the industry. This activity could be part of a firm's strategic management process. Core values a could be specified which [1] act on those threats and opportunities, [2] incorporate the guidance of ethical philosophies such as deontology and utilitarianism, and [3] fit or enhance the existing organizational culture. Developed during the strategic management process, a code of business ethics could become a part of the documentation for an organization's culture. The code could have "impact" and be proactive. The document could contain broad values that have been carefully devised to fit the environment of the firm. A code of business ethics developed in this way could be more responsive to the form's external and internal constituencies and needs. The result could be a document that all organizational members could understand, accept, and support. Many individuals should have input into develoment of the document.

Laczniak and Naor [21] offer four recommendations for developing a code of business ethics in multinational corporations. First, codes of business ethics of multinational corporations should be company-wide, regardless of the area of operation. Second, the codes should serve as input information in the strategy-formulation process. Third, when unbridgeable gaps appear between the ethical values of a host 
country and those of a multinational corporation, the multinational corporations should regularly develop and issue "ethical impact statements."

\section{Conclusion}

Less than 50 percent of the sample corporations in this study had developed a formal code of business ethics. This finding was unfortunate because it may be desirable for all firms to have a written code of business ethics. Cadbury [5] and Litzinger and Schaefer [22] stress the need for all organizations to develop a clear code of business ethics. A formal code of business ethics can be an effective tool for setting ethical boundaries in a firm. When an ethical boundary or variable is violated, swift action is needed to emphasize the importance of adhering to ethical standards of business conduct. Drucker [12], Gellerman [14], and Velasquez [26] emphasize that responsibility for developing and communicating a clear code of business ethics rests primarily with top managers or strategists of the firm. As such, business ethics should be an intergral part of the strategic management thought process.

This article provides information that could be used to develop a more effective code of business ethics. The results and implications of this study could provide impetus for more research that is needed to better understand the nature and role of codes of business ethics of America's "best" manufacturing and service firms are provided to give direction for top managers of other organizations. A "proactive" approach is recommended for developing and revising codes of business ethics.

\section{References}

1. Barach, J. A. "The Ethics of Hardball." California Management Review, Vol. 27, No. 2 (1985), pp. 132-39.

2. Barnard, C. I. The Functions of the Executive. Cambridge, MA: Harvard University Press (1968).

3. Behrman, J. N. Essays on Ethics in Business and the Professions. Englewood Cliffs, NJ: Prentice-Hall (1968).

4. Budd, R. W., R. K. Thorp, and L. Donohew. Conent Analysis of Communications. New York, NY: MacMillan Company (1967).

5. Cadbury, S. A. "Ethical Managers Make Their Own Rules." Harvard Business Review, Vol. 65, No. 2 (September/October 1987), pp. 69-73.

6. Carr, A. Z. "Is Business Bluffing Ethical?" Harvard Business Review (January/February 1968), pp. 20-29.

7. Center of Business Ethics. "Are Corporations Institutionalizing Ethics?" Journal of Business Ethics (April 1986), pp. 86-94. 
8. Chonko, L. B. and S. D. Hunt. "Ethics and Marketing Management; An Empirical Examination." Journal of Business Research (August 1985), pp. 356-66.

9. Clasen, E. A. "Marketing Ethics and the Consumer." Harvard Business Review (January/February 1967), pp. 79-85.

10. Cressey, D. R. and C. A. Moore. "Managerial Values and Corporate Codes of Ethics." California Management Review (Summer 1983), pp. 73-80.

11. David, F. R. Strategic Management, second edition. Columbus, OH: Merrill Publishing Company (1989, in press).

12. Drucker, P. Management: Tasks, Responsibilities, and Practices. New York, NY: Harper \& Row, Publishers (1974).

13. Epstein, E. M. "The Corporate Social Policy Process: Beyond Business Ethics, Corporate Social Responsibility, and Corporate Social Responsiveness." California Management Review (Spring 1987), pp. 99-114.

14. Gellerman, S. W. "Why 'Good' Managers Make Bad Ethical Choices." Harvard Business Review (July/August 1986), pp. 85-90.

15. Genfan, H. "Formalizing Business Ethics." Training and Development Journal (Summer 1987), pp. 35-37.

16. Goldhaber, G. M. Organizational Communication, third edition. Dubuque, IA: William C. Brown Company (1983).

17. Hauserman, N. R. "Whistle-Blowing: Individual Morality in a Corporate Society." Business Horizons (March/April 1986), pp. 4-9.

18. Horton, N. R. "The Ethics of Crisis Continues: What To Do." Management Review (November 1986), p. 3.

19. Keifer, F. "What Some Companies are Doing to teh Ethical Line." Christian Science Monitor (October 1983), pp. 13-14.

20. Kelly, C. M. "The Interrelationship of Ethics and Power in Today's Organizations.” Organizational Dynamics (Summer 1987), pp. 4-18.

21. Laczniak, G. R. and J. Naor. "Global Ethics: Wrestling with the Corporate Conscience." Business (July/September 1985), pp. 3-10.

22. Litzinger, W. D. and T. E. Schaefer. "Business Ethics Bogeyman: The Perpetual Paradox." Business Horizons (March/April 1987), pp. 16-21.

23. Loucks, V. R. Jr. "A CEO Looks at Ethics." Business Horizons (March/April 1987), pp. 2-6. 
24. Pastin, M. "Business Ethics, By the Book." Business Horizons (January/ February 1985), pp. 2-6.

25. Steiner, G. A. Business and Society: Cases, second edition. New York, NY: Random House (1972), pp. 211.

26. Velasquez, M. G. Business Ethics: Concepts and Cases, second edition. Englewood Cliffs, NJ: Prentice-Hall (1988).

27. Wokutch, R. E. and B. A. Spencer. "Corporate Saints and Sinners: The Effects of Philanthropic and Illegal Activity on Organizational Performance." California Management Review, Vol. 29, No. 2 (1987), pp. 62-77. 